\title{
Development of an antigen-biotin conjugate with a protein bridge and its application for the development of an enzyme immunoassay
}

\section{Viviana Graciela Spotorno \& Jorge Guillermo Tezón}

To cite this article: Viviana Graciela Spotorno \& Jorge Guillermo Tezón (2012) Development of an antigen-biotin conjugate with a protein bridge and its application for the development of an enzyme immunoassay, Food and Agricultural Immunology, 23:4, 315-328, DOI:

10.1080/09540105.2011.629314

To link to this article: https://doi.org/10.1080/09540105.2011.629314

曲 Published online: 01 Nov 2011.

Submit your article to this journal ๘

Щ Article views: 101

Citing articles: 1 View citing articles $₫$ 


\title{
Development of an antigen-biotin conjugate with a protein bridge and its application for the development of an enzyme immunoassay
}

\author{
Viviana Graciela Spotorno ${ }^{\mathrm{a} *}$ and Jorge Guillermo Tezón ${ }^{\mathrm{b}}$ \\ ${ }^{a}$ Instituto Tecnología de Alimentos, INTA, c.c. 77, 1708, Morón, Argentina; ${ }^{b}$ Instituto de \\ Medicina y Biología Experimental, CONICET, Vuelta de Obligado, 2490 Buenos Aires, C1428, \\ $A D N$, Argentina
}

(Received 21 May 2011; final version received 17 September 2011)

\begin{abstract}
Antigens with aromatic amino groups can be conjugated to proteins by a diazo bond. This property was used to synthesise an antigen-biotin conjugate using bovine serum albumin (BSA) as a bridge, and tested this conjugate in an enzymoimmunoassay for clenbuterol detection. The assay included a highly specific antibody and the biotin-avidin amplification system. Its coefficient of variation was lower than $20 \%$ in the range of $100-8000$ pg per well and the limit of detection was $6.4 \mathrm{pg}$. The synthesis of clenbuterol-BSA-biotin conjugate was reproducible, the reaction product easily purified and the amplification capacity could be set by adjusting the clenbuterol:biotin ratio.
\end{abstract}

Keywords: immunoassay; clenbuterol; conjugated; avidin; biotin

\section{Introduction}

Aromatic amino groups from an antigen can be diazotised with nitrous acid to form diazonium compounds. The diazonium group will react with phenolic, imidazole and amino side chains of a protein to form a diazo bond. This paper proposes to use this method for the construction of a conjugate of clenbuterol, a well known anabolic that is administered to cattle to improve meat rate and reduce animal fat (Smith \& Paulson, 1997; Smith, 1998; Kuiper, Noordam, van Dooren-Flipsen, Schilt, \& Roos, 1998; Mitchell \& Dunnavan, 1998). Clenbuterol is a B-adrenergic agonist that mimics the activity of adrenaline and noradrenaline (Fiems, 1987; Mersmann, 1998). It is used for the treatment of bronchial diseases but, because it has also been used illegally as a growth-promoting agent in meat production, it is being extensively controlled as a veterinary drug residue in food safety. The residues of clenbuterol which accumulate in animal tissues can cause symptoms of acute poisoning in humans (Brambilla et al., 2000; Kuiper, Noordam, Dooren-Flipsen, Schilt, \& Roos, 1998; Meyer \& Rinke, 1991; Mitchell \& Dunnavan, 1998).

Detection limits for residue control must be within the range of ng per tissue gram. This can be achieved by HPLC or capillary electrophoresis with electrochemical detection (Blanchflower, Hewitt, Cannavan, Elliott, \& Kennedy, 1993; Boyd, O’Keefe, \& Smyth, 1996; Chen, Wang, Duan, Chen, \& Chen, 2005; De Wasch, De Brabander and Courtheyn, 1998; Gleixner, Sauerwein, \& Meyer, 1996;

*Corresponding author. Email: vspotorno@cnia.inta.gov.ar 
Hooijerink, Schilt, Haasnoot, \& Courtheijn, 1991; Lin, Tomlinson, \& Satzger, 1997; Polettini et al., 1995), highly sensitive immunoassays or HPLC or GC with MS detection (Abukhalaf et al., 2000; Blanca et al., 2005; Guy, Savoy, \& Stadler, 1999; $\mathrm{He}, \mathrm{Su}$, Zeng, Liu, \& Huang, 2007). These instrumental techniques, although selective and sensitive with low detection methods, are expensive and require a big amount of sample. For these reasons, immunoassays are the screening methods of choice in determining illegal use.

The first enzymoimmunoassay (EIA) for clenbuterol was developed by Yamamoto and Iwata in 1982 (Yamamoto \& Iwata, 1982). Since then, many other EIAs, with a wide range of use, including enzyme-clenbuterol conjugate, have been reported (Bucknall et al., 1993; Degand, Bernes-Duyckaerts, \& MaghuinRogister, 1992; Haasnoot, Stouten, Schilt, \& Hooijerink, 1998; Meyer \& Rinke, 1991; Posyniak, Zmudzki, \& Niedzielska, 2003; Ren, Zhang, Chen, \& Yang, 2009; Sauer, Pickett, \& Mac Kenzie, 1993). Further, publications have described immunobiosensor methods for screening, with immobilised antigen or antibody (Chen \& Li, 2007; Johansson \& Hellenäs, 2001; Johansson \& Hellenäs, 2003; Traynor, Crooks, Bowers \& Elliott, 2003). Recently, electrochemical immunosensors have gained growing attention because they combine the high specificity of traditional immunoassay methods with the low detection limits and low expenses of electrochemical measurement system (He, Wang, Zhang, \& Yang, 2009).

Although the development of a $\beta$-agonist-biotin conjugate, and its successful use in a clenbuterol EIA has been published (Rinke \& Dürsch, 1991; Yamamoto \& Iwata, 1982) to our knowledge, there is no clenbuterol-biotin conjugate previously described.

The objective has been developed an antigen-biotin conjugate using a protein as a bridge. Clenbuterol and EIA were used to characterise this conjugate, which can be of general application for most antigens with aromatic amino groups, and other immunoassay designs.

\section{Experimental}

\subsection{Preparation and purification of the protein-clenbuterol conjugate}

Conjugation of bovine serum albumin (BSA) to clenbuterol was performed by the diazotised method of Yamamoto and Iwata(1982). Briefly, $3 \mathrm{mg}$ of $\mathrm{NaNO}_{2}$ dissolved in $200 \mu \mathrm{L}$ of distilled water was added drop-wise to $3 \mathrm{mg}$ of clenbuterol $\mathrm{HCl}$ in $400 \mu \mathrm{L}$ of water and $100 \mu \mathrm{L}$ of $1 \mathrm{~N} \mathrm{HCl}$, under dark conditions at $4{ }^{\circ} \mathrm{C}$, with continuous stirring. After $30 \mathrm{~min}$, unreacted $\mathrm{NO}_{2}^{-}$was eliminated by the addition of $7 \mathrm{mg}$ of ammonium sulfamate in $140 \mu \mathrm{L}$ of water until there were no more bubbles. Diazo-clenbuterol was detected by a yellow-coloured reaction by adding $50 \mu \mathrm{L}$ of $N, N$-dimethyl aniline to $10 \mu \mathrm{L}$ of the reaction mixture. Then, $150 \mu \mathrm{L}$ of the diazoderivate was added drop-wise to $40,6,3$ and $0 \mathrm{mg}$ of BSA in $200 \mu \mathrm{L}$ of $0.1 \mathrm{M}$ $\mathrm{pH}=7.5$ sodium phosphate buffer. The $\mathrm{pH}$ was adjusted to 7 with $1 \mathrm{~N} \mathrm{NaOH}$ (about $15 \mu \mathrm{L}$ ). The preparation was allowed to stand overnight in darkness at $5^{\circ} \mathrm{C}$. Finally, the clenbuterol-BSA (clen-BSA) conjugate was purified by centrifugal filter devices with a YM-30 membrane of regenerated cellulose (Centricom, Millipore), which provides concentration and desalting of macromolecules over a 30,000 Da molar weight. The filtrate was tested by HPLC-UV $280 \mathrm{~nm}$, with a C18 column (Vydac, 
$5 \mu \mathrm{m}, 150 \times 45 \mathrm{~mm})$ and acetonitrile:buffer $\left(20 \mathrm{mM} \mathrm{KH}_{2} \mathrm{PO}_{4}, \mathrm{pH}=4.4\right)(1: 4)$ at $1 \mathrm{~mL} / \mathrm{min}$. The optimum proportion of diazo-clenbuterol to BSA for the coupling reaction was established as $0.5 \mathrm{mg}$ of diazo-clenbuterol to $6 \mathrm{mg}$ of $\mathrm{BSA}$, by testing the reduction of free diazo-clenbuterol in the chromatogram of the filtrate.

To obtain a high molecular weight immunogen for antibody production, the diazo-clenbuterol was coupled to human serum albumin (HSA) using the same methodology.

\subsection{Preparation of the clenbuterol-BSA-biotin (CBB) conjugate}

To obtain a CBB conjugate, clen-BSA was labelled using a common procedure to couple biotin residues to proteins. Fresh solution of $10 \mathrm{mg} / \mathrm{ml} N$-hydroxysuccinimido-biotin (NHS-Biotin) (from Pierce) in dimethyl sulfoxide was prepared and different volumes of this solution containing: $300,100,35$ and $10 \mu \mathrm{g}$, were added drop-wise on $100 \mu \mathrm{g}$ of clem-BSA in $110 \mu \mathrm{L}$ of $0.1 \mathrm{M}$ sodium borate buffer, $\mathrm{pH}=8.8$. After incubation in darkness, at room temperature for 2 to $3 \mathrm{~h}$, the reaction mixture was allowed to stand at $4{ }^{\circ} \mathrm{C}$ overnight. The reaction was stopped by the addition of $30 \mu \mathrm{L}$ of $1 \mathrm{M} \mathrm{NH}_{4} \mathrm{Cl}$. The biotinylated clen-BSA (CBB) was then dialysed against phosphate buffered saline (PBS) at $4^{\circ} \mathrm{C}$ overnight.

\subsection{Immunisation. IgG fraction purification from antiserum}

Antibody against clenbuterol (anti-clen) was produced in rabbits by intradermal immunisation. The first dose of $0.5 \mathrm{mg}$ clenbuterol-HSA conjugate (clen-HSA) was administered to rabbits in complete Freund's adjuvant, and the booster doses of $0.2 \mathrm{mg}$ of the immunogen in incomplete Freund's adjuvant at two-week intervals. After the fifth booster, $12 \mathrm{~mL}$ of blood was taken from the ear vein, and tested for clenbuterol antibodies by immunodiffusion in agar, using clen-HSA and clen-BSA as antigens in the presence of an excess of BSA to block any cross-reaction to serum albumin. This experiment was performed in compliance with the relevant laws and institutional guidelines approved by the authorities of the Instituto de Biología $y$ Medicina Experimental (IByME), Buenos Aires, Argentina.

In order to obtain the IgG fraction from the serum, a column was prepared with $200 \mu \mathrm{L}$ of protein A immobilised on Sepharose 4B (from Sigma) suspension and washed with five volumes of 5\% BSA in PBS. The column was then loaded with $800 \mu \mathrm{L}$ of serum diluted with $50 \mu \mathrm{L}$ of $1 \mathrm{M}$ Tris buffer, $\mathrm{pH}=8.5$. After washes with $2 \mathrm{ml}$ of the same buffer, the IgG fraction was eluted with $800 \mu \mathrm{L}$ of $\mathrm{HCl} \mathrm{pH}=2.5$ $\mathrm{NaCl} 100 \mathrm{mM}$. At this $\mathrm{pH}$, antibodies suffer Fab denaturalisation. The eluted fraction was diluted (1:2) in washing buffer and stored at $4{ }^{\circ} \mathrm{C}$. Total protein concentration was calculated by UV absorbance at $280 \mathrm{~nm}$.

\subsection{Competitive enzymoimmunoassay}

The anti-clen was denaturalised by lowering the $\mathrm{pH}$ to 2.5 with $\mathrm{HCl}$ and $\mathrm{NaCl}$ $100 \mathrm{mM}$ for $10 \mathrm{~min}$, readjusting to $\mathrm{pH} 8$ with $0.1 \mathrm{M}$ sodium phosphate buffer. Polyestyrene strips Maxisorp (from Nunc) were coated by incubation with $100 \mu \mathrm{L}$ of the antibody solution at different concentrations in the same buffer per well and incubated at room temperature overnight. After washing with PBS $0.02 \%$ 
Tween 20, the wells were blocked with $400 \mu \mathrm{L} 5 \%$ BSA in PBS, at room temperature for $1 \mathrm{~h}$. The strips coated with anti-clen could be stored dried at $4{ }^{\circ} \mathrm{C}$ without loss of activity.

For the assay, $100 \mu \mathrm{L}$ of samples or clenbuterol standard solutions (100, 20, 4, $0.8,0.16,0.032,0.0064$ and $0 \mathrm{ng} / 100 \mu \mathrm{L})$ in $0.1 \%$ BSA and $0.02 \%$ Tween 20 in PBS were added to coated wells with $100 \mu \mathrm{L}$ of $\mathrm{CBB}$ at a proper concentration for each experiment in the same buffer, and incubated at room temperature for $2 \mathrm{~h}$. After extensive washing, the wells were incubated with $100 \mu \mathrm{L}$ of Extr-Avidin Alkaline Phosphatase (EAP, Sigma), at the recommended dilution (1:2000) in PBS 0.1\% BSA, at room temperature for $1 \mathrm{~h}$, and the presence of the enzyme was detected by the phosphatase reaction with $100 \mu \mathrm{L}$ of $1 \mathrm{mg} / \mathrm{ml} p$-nitrophenylphosphate in $1 \mathrm{M}$ diethanolamine $\mathrm{pH}=9.8,0.5 \mathrm{mM} \mathrm{MgCl}_{2}$ ( $\mathrm{pNPP}$ ) at room temperature. The absorbance was read at $405 \mathrm{~nm}$ after $30 \mathrm{~min}$. The reaction could be stopped by the addition of $100 \mu \mathrm{L}$ of $1 \mathrm{M} \mathrm{NaOH}$.

\subsection{Calculation of results}

The software package I-Smart 2.0 (Packard Bioscience Company) was used to fit the four-parameter logistic curve:

$$
Y=(A-D) /\left[1+(X / C)^{B}\right]+D
$$

where $A$ is the absorbance at zero concentration of clenbuterol and $D$ is response at infinite concentration (clenbuterol $100 \mathrm{ng} / 100 \mu \mathrm{L}$ ). $C$ represents the half maximal inhibitory concentration (IC50), a measure of the effectiveness of a compound in inhibiting the antibody bound and the concentration resulting in the response which is halfway between $A$ and $D$.

The precision profile gives the relation of standard deviation (SD) of concentration $(\Delta C)$ or coefficient of variation $(\mathrm{CV})$ of the concentration $(\Delta C / C)$ as a function of the dose. The $\mathrm{CV} \%$ was calculated using the same software.

\subsection{Hair samples}

Three Holando-Argentino steers aged 2.5 to 3 years old and approximately $450 \mathrm{~kg}$ were used in the experiment. Their phenotype is of white hair with wide regions of black hair. Two of them were treated by intravenous injection of $10 \mathrm{ml}$ of a veterinary formulation, $1.95 \mathrm{mg}$ of clenbuterol according to protocol instructions. The animals were grass-fed and had free access to water. After 25 days, black hair samples were taken from the animal's back. All samples were kept at $4{ }^{\circ} \mathrm{C}$ until analysis.

This experiment was performed in compliance with the relevant laws and institutional guidelines approved by the authorities of the Instituto Nacional de Tecnología Agropecuaria (INTA), Argentina.

\subsection{Sample preparation}

Bovine hair samples were washed with $1 \%$ of SDS and rinsed with water. After drying, $100 \mathrm{mg}$ of sample was heated with $2.5 \mathrm{~mL}$ of $5 \mathrm{M} \mathrm{NaOH}$ for $10 \mathrm{~min}$ at $95^{\circ} \mathrm{C}$. When the samples reached room temperature, $3 \mathrm{~mL}$ of $t$-butylmethylether was 
added. The mixture was stirred by vortex, incubated for $15 \mathrm{~min}$ in ultrasonic bath and mixed by rotation for another $15 \mathrm{~min}$ at room temperature. The last two steps were repeated and the organic phase was collected and evaporated to dryness (Haasnoot, Stouten, Schilt and Hooijerink, 1998). The residue was dissolved in methanol and diluted (1:10) in EIA buffer.

\section{Results}

\subsection{Clen-BSA conjugate and antibody production}

The best ratio for the conjugation of clenbuterol to BSA was $0.5 \mathrm{mg}$ of diazoclenbuterol to $6 \mathrm{mg}$ of BSA. Immunogenicity is determined by its chemical structure and the immune system capability to react and produce antibodies. Small molecules have to be coupled to proteins to facilitate this immuno-reaction. To obtain antibodies against clenbuterol, rabbits were immunised with already prepared clen-HSA conjugate. HSA in the antigen would avoid cross-reaction of the serum to the BSA in the CBB conjugate used in the EIA. The serum obtained was tested against clen-BSA and clen-HSA by immunodiffusion in agar. Bands of precipitation with both antigens indicated that antibodies in the serum can recognise clenbuterol residues in the clen-BSA and clen-HSA molecules. After purification, the $\mathrm{IgG}$ fraction containing $2.7 \mathrm{mg} / \mathrm{mL}$ of protein was used in the following experiments.

\section{2. $C B B$ conjugate}

The purpose of designing this conjugate was to obtain a molecule with two binding moieties: a clenbuterol reactive to antibodies, and a biotin to bind avidin-enzyme complexes. The number of relative enzymes bound to the conjugate would determine the degree of signal amplification. Our first attempt was to couple directly NHS-biotin to clenbuterol. This reaction did not produce a derivate with the two moieties useful for an assay (data not shown).

The coupling reaction of diazo-clenbuterol to BSA is achieved by tyrosine phenolic groups of the protein. NHS-Biotin reacts any primary amine-containing molecule to attach the biotin label via a stable amide bond, then this reaction enabled simple and efficient biotin labelling of the protein-clenbuterol conjugate (Figure 1). This synthesis was carried out six different times with similar performance for CBB obtained in the titration curves.

A conjugate for wide use in EIAs must fulfil the following requirements: chemical purity, stability, reproducible antigen-biotin ratio and active binding to avidin-enzyme complexes, which are commercially available and suitable for the amplification of the signal.

The EIA finally designed is schematised in Figure 2(a). A preliminary competitive EIA experiment was performed with CBB synthesised with $100 \mu \mathrm{g}$ of NHS-biotin. Signal reduction was observed in the presence of clenbuterol in the incubation media, indicating immunospecific reaction to clenbuterol residues in CBB (Figure 2(b)).

The conjugates coupled with different amounts of NHS-biotin were titrated in the same range of dilutions for comparison (Figure 3). For this experiment, strips were prepared with anti-clen at a 1:2000 dilution of the serum. 


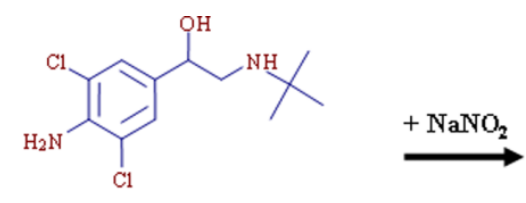

Clenbuterol

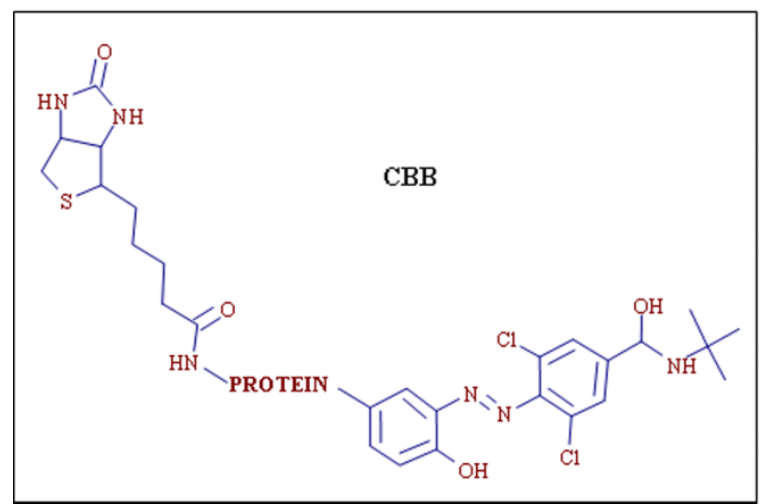

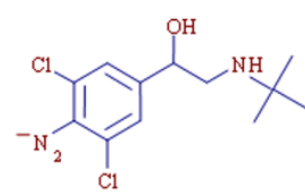

$\mathrm{H}_{2} \mathrm{~N}$
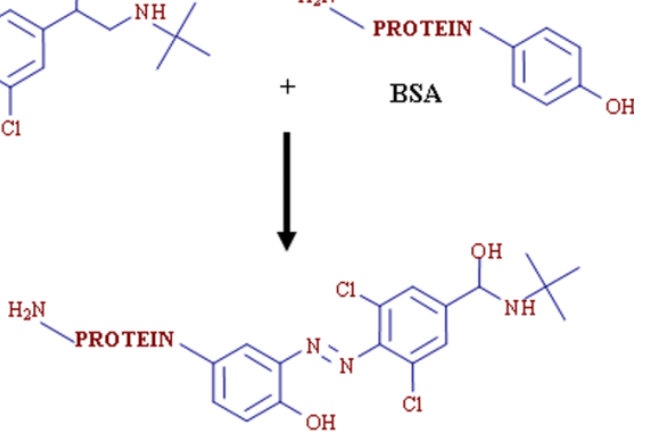

Clen-BSA

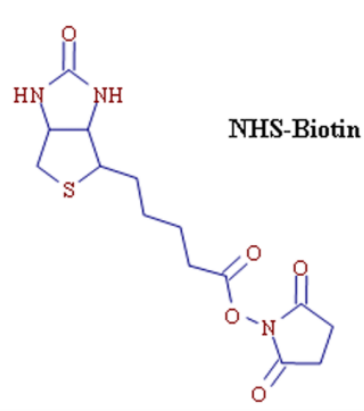

Figure 1. Coupling reaction of diazo-clenbuterol to proteins and biotinilation. 
(a)

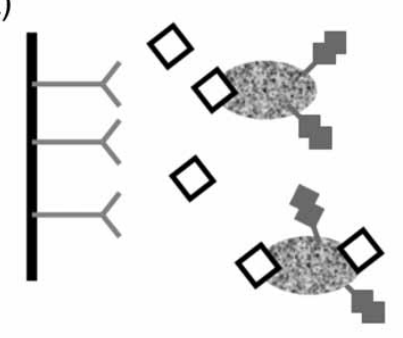

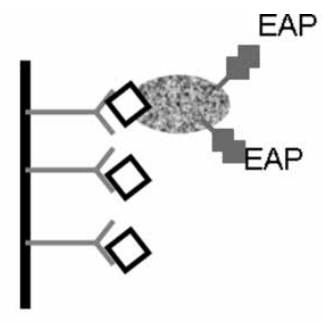

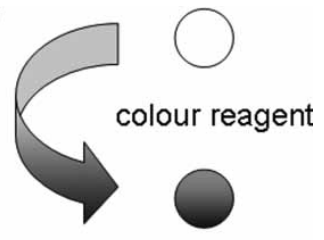

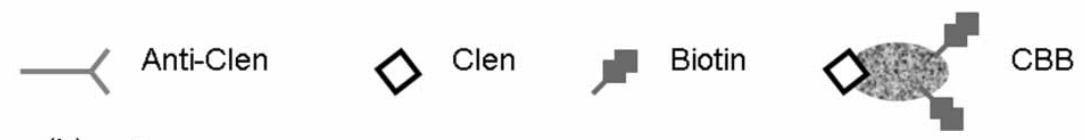
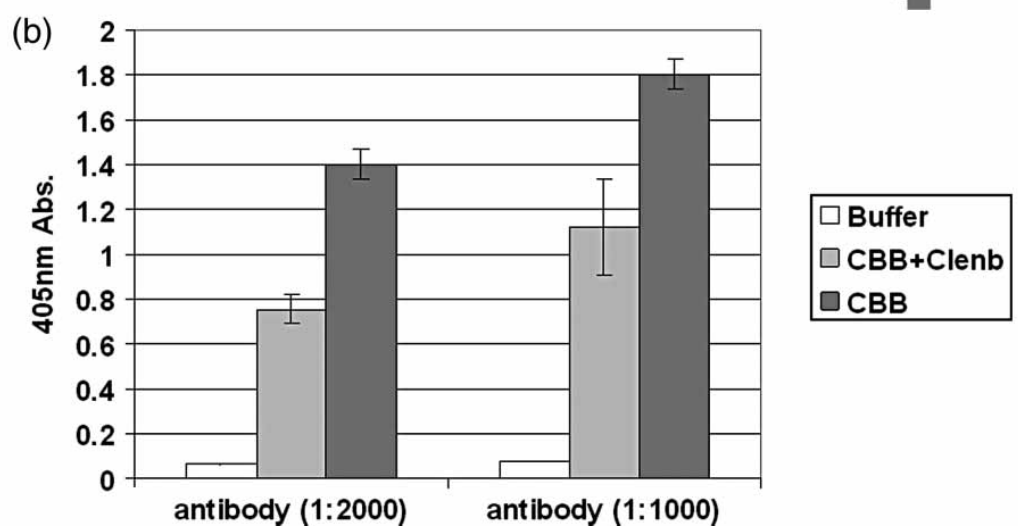

Figure 2 (a). Competitive EIA. Clenbuterol competes with CBB for antibody binding, followed by incubation with EAP. The antibody-CBB-EAP complex is finally detected by pNPP colour reaction. $\mathbf{b}$. Effective antibody-CBB reaction. Strips were prepared with anti-clen at two different serum dilutions (1:2000 and 1:1000), and reacted with $100 \mu \mathrm{L}$ of $15 \mathrm{ng} / \mu \mathrm{L}$ $\mathrm{CBB}$ and $100 \mu \mathrm{L}$ of either buffer or $20 \mathrm{ng} / 100 \mu \mathrm{L}$ clenbuterol.

The signal increased with the highest number of biotin coupled to the conjugate within the range of 10-100 $\mu \mathrm{g}$. At higher quantities of NHS-Biotin in the reaction, a saturation effect could be seen. It could not be established whether this limit was due to saturation of available sites for biotinylation of the BSA, or steric hindrance for the binding of many EAP molecules on the conjugates. Thereby, CBB synthesised from $100 \mu \mathrm{g}$ of NHS-biotin was the conjugate chosen for the following experiments. It was used at 1:6000 dilution $\left(1.110^{-4} \mathrm{mg} / \mathrm{mL}\right)$, corresponding to the middle point of the curve.

The anti-clen was titrated at those conditions. The better dilution that assured maximum signal displacement in the presence of $100 \mathrm{ng}$ of clenbuterol per well was 1:2000 from the serum $\left(2.710^{-3} \mathrm{mg} / \mathrm{mL}\right.$ of protein) (data not shown).

\subsection{EIA, calibration curve}

In Figure 4, a calibration curve in the range from 100 to $0.0064 \mathrm{ng} / 100 \mu \mathrm{L}$ clenbuterol per well is shown. Strips were covered with anti-clen (1:2000) and CBB 

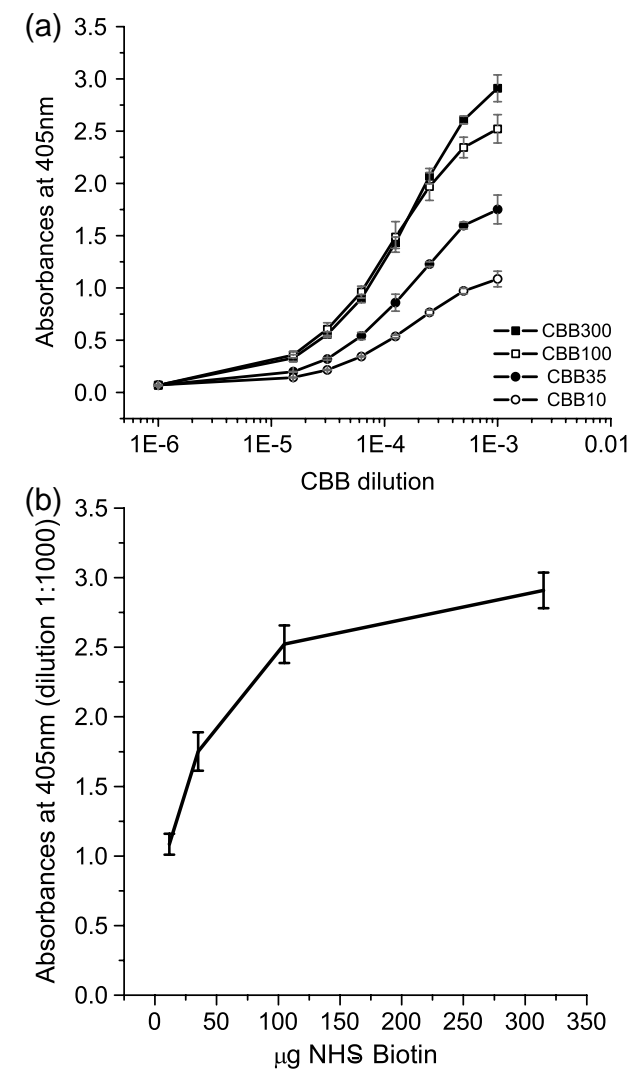

Figure 3 (a). Titration curves of different CBB coupled with 300, 100, 35 and $10 \mu \mathrm{g}$ of NHSBiotin. The curves depicted the average of two different experiments. (b). Maximal absorbance of experiments depicted on Figure 3(a). vs. microgram of NHS-Biotin.

was used at 1:6000 dilution. The addition of 10\% methanol in the standard solutions changed the IC50 from $0.33 \mathrm{ng} / 100 \mu \mathrm{L}$ to $0.44 \mathrm{ng} / 100 \mu \mathrm{L}$. This finding is very important, especially in residue analysis, where laborious sample preparation procedures, which usually end in methanol extracts, are usually required.

\subsection{Specificity}

At the established conditions, the EIA was tested for specificity. The cross reactivity of different agonists to the anti-clen antibody in the EIA is summarised in Table 1. The antibody showed very small cross-reaction with the endogenous agonist epinephrine. However, the affinity for clenbuterol was 500 times higher.

\subsection{Calibration curve and precision assay}

An average curve resulting from nine independent calibration curves in duplicate was obtained. Its parameters are the following: $A=0.985, B=0.722, C=0.525$ and 


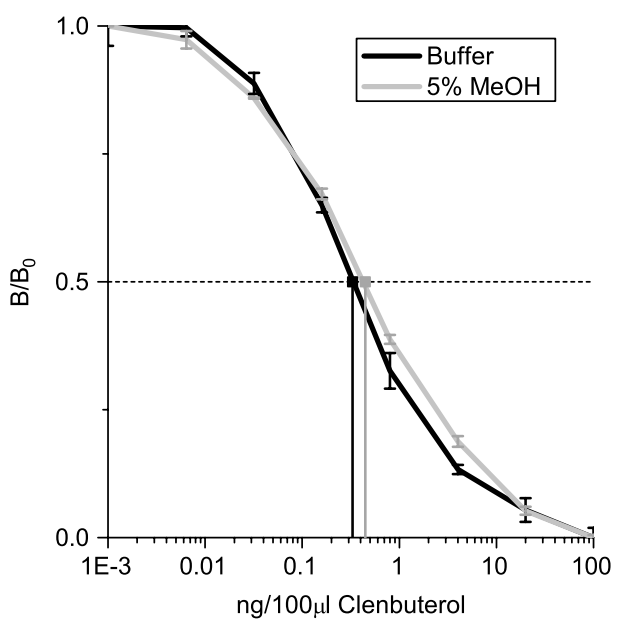

Figure 4. Typical calibration curves for clenbuterol by EIA. The strips were prepared with anti-clen (1:2000). The incubation well contained $100 \mu \mathrm{L} \mathrm{CBB} \mathrm{(1:6000)} \mathrm{and} \mathrm{clenbuterol} \mathrm{from}$ zero to $100 \mathrm{ng} / 100 \mu \mathrm{L}$ in buffer or in $10 \%$ methanol buffer in $200 \mu \mathrm{L}$ final volume. Each curve represents the average of three different experiments.

$D=0.013$, with $R^{2}=0.999$. Then, the limit of detection and the calibration graph mid-point were estimated at 6.4 and $525 \mathrm{pg}$ per well, respectively.

The $\mathrm{CV} \%$ of each point was obtained by the average of $\mathrm{CV} \%$ of dose-response curves from nine experiments in duplicate. The $\mathrm{CV}$ for the calibration curve of the assay was minimum at the IC50 $(0.52 \mathrm{ng} / 100 \mu \mathrm{L})$, and increased at concentrations higher than $10 \mathrm{ng} / 100 \mu \mathrm{L}$ and lower than $0.001 \mathrm{ng} / 100 \mu \mathrm{L}$ (Figure 5). The range of the curve with a CV lower than $20 \%$ was observed between 0.1 and $8 \mathrm{ng} / 100 \mu \mathrm{L}$ or between 100 and 8000 pg per well.

Table 1. Antibody cross-reaction.

\begin{tabular}{lc}
\hline Agonist & IC50 (ng/mL) \\
\hline Clenbuterol & 3.6 \\
Mabuterol & 35.0 \\
Methaprolol & 55.0 \\
Propanolol & 149.4 \\
Bromobuterol & 171.6 \\
Zinterol & 414.4 \\
Isoproterenol & 520.6 \\
l-Epinephrine & 1808.2 \\
Cinbuterol & 2125.9 \\
Salbutamol & 2924.6 \\
Phenylephrine & 3891.8 \\
\hline
\end{tabular}




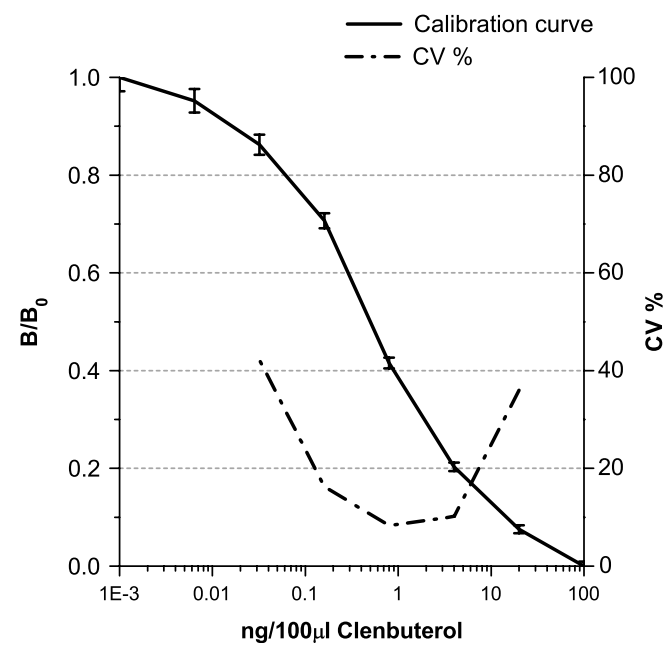

Figure 5. Precision profile. Calibration curve and CV calculated from nine different assays run in duplicate.

\subsection{Clenbuterol concentration in hair of treated animals}

The performance of the assay in typical residue analysis was evaluated. The residue accumulation in bovine hair samples was analysed after in vivo injection of clenbuterol as described earlier, and the results are shown in Table 2. After 25 days, significant residues of clenbuterol in hair were observed in the treated animals.

\section{Discussion}

\subsection{Synthesis of biotinylated conjugate and its applicability}

The biotinylated conjugate $(\mathrm{CBB})$ described here showed to be very convenient for several reasons: it exhibits specific reaction to the antibody, its synthesis and purification are simple and reproducible, and it is stable for months at $4{ }^{\circ} \mathrm{C}$. The coupling of clenbuterol and biotin to BSA at the conditions here described assures both the reaction antigen-antibody and the avidin-biotin complex (Figure 1). NHSactivated biotins react efficiently with primary amino groups to form stable amide bonds. Proteins have primary amines in the side chain of lysine residues and Nterminus. The manufacture's procedure for biotinilating proteins ordinary will yield incorporation of 3-5 or more (8-12) biotins per molecule of protein, especially when greater molar excess of biotin reagent was used. BSA molecular weight is about 66 $\mathrm{KDa}$, and is composed of nearly 600 amino acid residues from which 60 are lysine residues. In present experiment, 20-, 70-, 200- and 580-fold molar excess of biotin

Table 2. Clebuterol concentration in bovine black hair.

\begin{tabular}{lccc}
\hline Animals & A (control) & B & C \\
\hline Clenbuterol concentration & $2 \pm 2 \mathrm{ng} / \mathrm{g}$ & $107 \pm 2 \mathrm{ng} / \mathrm{g}$ & $49 \pm 1 \mathrm{ng} / \mathrm{g}$
\end{tabular}


were used in the labelling reactions, that means $0.3,1,3$ and more than ninefold molar excess of lysine in the CBB10, 35, 100 and 300. On the other hand, random biotinylation of lysine residue can greatly alter the functional properties of the molecule or its capacity to be recognised by an antibody. In our case, by increasing the NHS-biotin in the coupling reaction, a correlation in the amplification effect could possibly be seen due to an increased number of biotin residues coupled to the protein in the conjugate. At higher concentrations of biotin, steric hindrance of the extra-avidin (EAP) enzyme complex could be responsible for the saturation effect. The exact number of residues of clenbuterol and biotin in the CBB molecule has not been established at this stage of the research. However, the performance of conjugate in the assay showed clearly the two functional moieties rendering an amplification effect.

\subsection{The antibody}

The specificity of the antiserum was characterised by the evaluation of its crossreaction with different agonists, being more active with clenbuterol. In the assay developed, the endogenous agonist epinephrine had to be 500 times higher than clenbuterol to obtain the same signal. This is particularly important for the assay of clenbuterol in tissues where epinephrine could be present. Biotinylated $\beta$-adrenergic agonists have been developed and used in an EIA for clenbuterol by Rinke and Dürsch (1991). In that experiment, free clenbuterol in the sample prevents biotinylated salbutamol binding to the anti-clenbuterol antibody. In that situation, the assay fails to disguise salbutamol from clenbuterol. In our case, the specificity of the antibody and the appropriate biotinylated conjugate reduced interferences.

\subsection{EIA procedure}

The most important components of immunoassays are antibodies and conjugates which determine assay quality. The antibody coupled to the solid phase showed effective affinity reaction to the antigen and the conjugate. Several conjugates have been previously described for antigen and biotin acting as a bridge for EIA (Lacorn, Fleischer, Wiling, Steinhart, \& Claus, 2005; Mares, DeBoever, Stans, Bosmans, \& Kohen, 1995). These conjugates are of defined chemical structure, but, since there is only one residue for biotinylation, there is no amplification effect as the one described here. The use of BSA did not allow an exact calculation of the biotin residues per molecule of reactive clenbuterol. However, under controlled conditions, a reproducible degree of amplification could be achieved.

Our assay is based on chained affinity reactions: antibody-clenbuterol, biotin-EAP. It was demonstrated to be useful in a wide range of concentrations avoiding sample dilutions.

At the IC50 $0.52 \mathrm{ng} / 100 \mu \mathrm{L}$, a change to $0.57 \mathrm{ng} / 100 \mu \mathrm{L} 10 \%$ in clenbuterol concentration implies a response change from 0.500 to 0.483 , which is perfectly detected by a conventional EIA reader. The method described here was able to detect clenbuterol residues 25 days after a single dose of $1.95 \mathrm{mg}$ clenbuterol per animal. 


\section{Conclusion}

The continuous development of methods for residue analysis and physiological determinations is needed. The high detection limit of an immunoassay is sometimes accompanied with cross-reactions or unpredictable matrix effects. The present EIA showed to be sensitive, specific and robust, owing to a specific antiserum, a biotinylated conjugate with signal amplification ability and an appropriate design that minimised interferences. Although the EIA is a well-known technique, the design presented here led to an assay with improved stability and simplicity.

In the development of an immunoassay for small molecules, it is necessary to couple the molecule to proteins in order to function as immunogen for antibody production. Here, a novel approached for amplification in EIAs has been shown: the hapten clenbuterol was coupled to BSA which was later biotinilated. Therefore, a bi-functional conjugate was obtained, both reactive to an antibody and an enzymatic system. The use of this conjugate in an EIA was presented. This design would not be restricted to a particular signal and could be used in combination with a variety of commercially available products such us fluorescence probes, particles for electron microscopy and both soluble and insoluble enzyme products. This design could also be applied in other assays like immunosensors, immunocytochemistry and even cell sorting. Moreover, the signal amplification effect obtained with this bi-functional conjugate could be useful in other binding reactions such as receptor assays.

\section{Acknowledgements}

This work was supported by Banco Interamericano de Desarrollo (BID) and Secretaría de Ciencia y Técnica de la Nación Argentina (SECyT) (Grant 802-OC-AR:339).

\section{References}

Abukhalaf, I.K., Deutsch, D.A., Parks, B.A., Wineski, L., Paulsen, D., Aboul-Enein, H., et al. (2000). Comparative analytical quantitation of clenbuterol in biological matrices using GC-MS and EIA. Biomedical Chromatography, 14, 99-105.

Blanca, J., Muñoz, P., Orgado, M., Méndez, N., Aranda, A., Reuvers, T., et al. (2005). Determination of clenbuterol, ractopamine and zilpaterol in liver and urine by liquid chromatography tandem mass spectrometry. Analytical Chimica Acta, 529, 199-205.

Blanchflower, W.J., Hewitt, S.A., Cannavan, A., Elliott, C.T., \& Kennedy, D.G. (1993). Detection of clenbuterol residues in bovine liver, muscle, retina and urine using gas chromatography/mass spectrometry. Biological Mass Spectrometry, 22(6), 326-330.

Boyd, D., O'Keefe, M., \& Smyth, M.R. (1996). Methods for determination of $\beta$-agonists in biological Matrices. A Review. Analyst, 121, 1R-10R.

Brambilla, G., Cenci, T., Franconi, F., Galarini, R., Macri, A., \& Rondoni, F. (2000). Clinical and pharmacological profile in a clenbuterol epidemic poisoning of contaminated beef meat in Italy. Toxicology Letters, 114, 47-53.

Bucknall, S.D., MacKenzie, A.L., Sauer, M.J., Everest, D.J., Newman, R., \& Jackman, R. (1993). Determination of clenbuterol in bovine liver by enzyme immunoassay. Analytica Chimia Acta, 275, 227-230.

Chen, C., \& Li, X. (2007). Application of a biosensor for super-sensitive detector of clenbuterol. New Zealand Journal of Agricultural Research, 50(5), 689-695.

Chen, Y., Wang, W., Duan, J., Chen, H., \& Chen, G. (2005). Separation and determination of clenbuterol, cimaterol and salbutamol by capillary electrophoresis with amperometric detection. Electroanalysis, 17, 706-712.

De Wasch, K., De Brabander, H., \& Courtheyn, D. (1998). LC-MS-MS to detect and identify four beta-agonists and quantify clenbuterol in liver. Analyst, 123, 2701-2705. 
Degand, G., Bernes-Duyckaerts, A., \& Maghuin-Rogister, G. (1992). Determination of clenbuterol in bovine tissues and urine by enzyme immunoassay. Journal of Agriculture Food Chemistry, 40, 70-75.

Fiems, L.O. (1987). Effect of beta adrenergic agonists in animal production and their mode of action. Annales de Zootechnie, 36(3), 271-290.

Gleixner, A., Sauerwein, H., \& Meyer, H.H. (1996). Detection of the anabolic beta 2-adrenoceptor agonist clenbuterol in human scalp hair by HPLC/EIA. Clinical Chemistry, 42, 1869-1871.

Guy, P.A., Savoy, M.-C., \& Stadler, R.H. (1999). Quantitative analysis of clenbuterol in meat products using liquid chromatography-electrospray ionisation tandem mass spectrometry. Journal of Chromatography B, 736, 209-219.

Haasnoot, W., Stouten, P., Schilt, R., \& Hooijerink, D. (1998). A fast immunoassay for the screening of B-agonist in hair. Analyst, 123, 2707-2710.

He, L., Su, Y., Zeng, Z., Liu, Y., \& Huang, X. (2007). Determination of ractopamine and clenbuterol in feeds by gas chromatography-mass spectrometry. Animal Feed Science and Technology, 132, 316-323.

He, P., Wang, Z., Zhang, L., \& Yang, W. (2009). Development of a label-free electrochemical immunosensor based on carbon nanotube for rapid determination of clenbuterol. Food Chemistry, 112, 707-714.

Hooijerink, H., Schilt, R., Haasnoot, W., \& Courtheijn, D. (1991). Determination of clenbuterol in urine of calves by high-performance liquid chromatography with in series ultraviolet and electrochemical detection. Journal of Pharmaceutical Biomedical Analytical, 9(6), 485-492.

Johansson, M.A., \& Hellenäs, K.E. (2001). Sensor chip preparation and assay construction for immunobiosensor determination of beta-agonists and hormones. Analyst, 126(10), $1721-1727$.

Johansson, M.A., \& Hellenäs, K. (2003). Immunobiosensor analysis of clenbuterol in bovine hair. Food and Agricultural Immunology, 15, 197-205.

Kuiper, H.A., Noordam, M.Y., Dooren-Flipsen, M.M., van, Schilt, R., \& Roos, A.H. (1998). Illegal use of beta-adrenergic agonists: European community. Journal of Animal Science, 76, 195-207.

Lacorn, M., Fleischer, K., Wiling, S., Steinhart, G.H., \& Claus, R. (2005). Use of biotinilated $17 \beta$-estradiol in enzyme-immunoassay development: Spacer length and chemical structure of the bridge are the mail determinants in simultaneous streptavidin-antibody binding. Journal Immunology Methods, 297, 225-236.

Lin, L.A., Tomlinson, J.A., \& Satzger, R.D. (1997). Detection of clenbuterol in bovine retinal tissue by high-performance liquid chromatography with electrochemical detection. Journal of Chromatography A, 762, 275-280.

Mares, A., DeBoever, J., Stans, G., Bosmans, E., \& Kohen, F. (1995). Synthesis of a novel biotin-estradiol conjugate and its use for the development of a direct, broad range enzyme immunoassay for plasma estradiol. Journal Immunology Methods, 183, 211-219.

Mersmann, H.J. (1998). Overview of the effects of $\beta$-adrenergic receptor agonists on animal growth including mechanisms of action. Journal of Animal Science, 76, 160-172.

Meyer, H.H., \& Rinke, L.M. (1991). The pharmacokinetics and residues of clenbuterol in veal calves. Journal of Animal Science, 69(11), 4538-4544.

Mitchell, G.A., \& Dunnavan, G. (1998). Illegal use of b-adrenergic agonists in theUnited States. Journal Animal Science, 76, 208-211.

Polettini, A., Montagna, M., Hogendoorn, E.A., Dijkmanb, E., van Zoonen, P., \& van Ginkel, L.A. (1995). Applicability of coupled-column liquid chromatography to the analysis of $\beta$-agonists in urine by direct sample injection I. Development of a single-residue reversedphase liquid chromatography-UV method for clenbuterol and selection of chromatographic conditions suitable for multi-residue analysis. Journal Chromatography, 695, 19-31.

Posyniak, A., Zmudzki, J., \& Niedzielska, J. (2003). Screening procedures for clenbuterol residue determination in bovine urine and liver matrices using enzyme-linked immunosorbent assay and liquid chromatography. Analytical Chimica Acta, 483, 61-67. 
Ren, X., Zhang, F., Chen, F., \& Yang, T. (2009). Development of a sensitive monoclonal antibody-based ELISA for the detection of clenbuterol in animal tissues. Food and Agricultural Immunology, 20(4), 333-344.

Rinke, L., \& Dürsch, I. (1991). Residue screening for the beta-agonists clenbuterol, salbutamol and cimaterol in urine using enzyme immunoassay and high-performance liquid chromatography. Journal of Chromatography, 564(2), 551-556.

Sauer, M.J., Pickett, R.J.H., \& Mac Kenzie, A.L. (1993). Determmination of clenbuterol residues in bovine liver, urine and eye by enzyme immunoassay. Analytica Chimica Acta, 275, 195-203.

Smith, D.J. (1998). The pharmacokinetics, metabolism, and tissue residues of $\beta$-adrenergic agonists in livestock. Journal of Animal Science, 76, 173-194.

Smith, D.J., \& Paulson, G.D. (1997). Distribution, elimination, and residues of [14C]Clenbuterol $\mathrm{HCl}$ in holstein calves. Journal of Animal Science, 75, 454-461.

Traynor, I.M., Crooks, S.R.H., Bowers, J., \& Elliott, C.T. (2003). Detection of multibeta-agonist residues in liver matrix by use of a surface plasma resonance biosensor. Analytical Chimica Acta, 483, 187-191.

Yamamoto, I., \& Iwata, K. (1982). Enzyme immunoassay for clenbuterol, and B2-adrenergic stimulants. Journal of Immunoassay, 3, 155-171. 